\title{
North Atlantic 20th century multidecadal variability in coupled climate models: sea surface temperature and ocean overturning circulation
}

\author{
I. Medhaug and T. Furevik \\ Geophysical Institute and Bjerknes Centre for Climate Research, University of Bergen, Bergen, Norway \\ Received: 12 January 2011 - Published in Ocean Sci. Discuss.: 10 February 2011 \\ Revised: 19 May 2011 - Accepted: 31 May 2011 - Published: 6 June 2011
}

\begin{abstract}
Output from a total of 24 state-of-the-art Atmosphere-Ocean General Circulation Models is analyzed. The models were integrated with observed forcing for the period 1850-2000 as part of the Intergovernmental Panel on Climate Change (IPCC) Fourth Assessment Report. All models show enhanced variability at multi-decadal time scales in the North Atlantic sector similar to the observations, but with a large intermodel spread in amplitudes and frequencies for both the Atlantic Multidecadal Oscillation (AMO) and the Atlantic Meridional Overturning Circulation (AMOC). The models, in general, are able to reproduce the observed geographical patterns of warm and cold episodes, but not the phasing such as the early warming (1930s-1950s) and the following colder period (1960s-1980s). This indicates that the observed 20th century extreme in temperatures are due to primarily a fortuitous phasing of intrinsic climate variability and not dominated by external forcing. Most models show a realistic structure in the overturning circulation, where more than half of the available models have a mean overturning transport within the observed estimated range of 13-24 Sverdrup. Associated with a stronger than normal AMOC, the surface temperature is increased and the sea ice extent slightly reduced in the North Atlantic. Individual models show potential for decadal prediction based on the relationship between the AMO and AMOC, but the models strongly disagree both in phasing and strength of the covariability. This makes it difficult to identify common mechanisms and to assess the applicability for predictions.
\end{abstract}

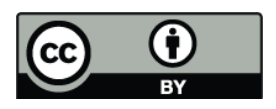

Correspondence to: I. Medhaug (iselin.medhaug@gfi.uib.no)

\section{Introduction}

The ocean currents transport vast amounts of heat from low to high latitudes by the horizontal wind-driven gyre circulation and the density-driven thermohaline circulation (THC), with a maximum of $\sim 2 \mathrm{PW}$ at $17^{\circ} \mathrm{N}$ (Trenberth and Caron, 2001). In the Atlantic these two components make up the Atlantic Meridional Overturning Circulation (AMOC), which in a zonal mean is characterized by a cell of northward flowing warm and saline water in the upper $1000 \mathrm{~m}$, above a southward flowing colder and fresher water down to 3$4000 \mathrm{~m}$. Below there is a deeper reversed cell of Antarctic bottom water (Delworth et al., 2008). The poleward transport of heat in the upper cell is an important driver for the climate system. At high latitudes the ocean is subjected to intense heat loss to the atmosphere and the water therefore loses buoyancy and sinks. The potential energy lost in the sinking process is regained by wind- and tidal mixing across stable stratification further south, and the deep water gradually returns to the surface (Wunsch, 2002). On very long time scales (order of 1000 years) the AMOC is therefore sustained by mechanical energy input through wind- and tidal mixing.

Decadal to multidecadal variability in the North Atlantic climate has been found in a large number of observational studies (e.g., Bjerknes, 1964; Kushnir, 1994; Schlesinger and Ramankutty, 1994; Delworth and Mann, 2000; Polyakov and Johnson, 2000), with two 20th century extremes being the early warming in the 1930 s to 1950 s, and the subsequent colder period during the 1960s to 1980s. From multimodel analysis of 20th century climate simulations, these temperature extremes have been attributed mainly to the internal variability of the North Atlantic and not to the externally forced responses (Kravtsov and Spannagle, 2008; Knight, 2009; Ting et al., 2009). However, other model simulations indicate that both solar variability and volcanoes contribute in setting the phase of the variability (Hansen et al., 2005; Otterå et al., 2010). The decadal to multidecadal temperature

Published by Copernicus Publications on behalf of the European Geosciences Union. 
variations observed in the Nordic Seas and the Arctic are seemingly related to the slowly varying SST field further to the south in the North Atlantic (Polyakov et al., 2004), where heat transport variability in both ocean and atmosphere appears to provide the link (e.g., Furevik, 2001). Bjerknes (1964) suggested that the decadal to multidecadal climate variations were driven by slow changes in the ocean gyre circulation, while many later studies indicate that the main cause is variations in the AMOC, driven by density fluctuations in the convection regions. The mechanisms suggested for this relationship include variations in the meridional heat and salt transports causing basin scale fluctuations in surface temperatures known as the Atlantic Multidecadal Oscillation (AMO; Delworth and Mann, 2000; Latif et al., 2004; Knight et al., 2005), and the effect heat and salinity anomalies have on the density in the convective regions, and hence the strength of the deep water formation (e.g., Delworth et al., 1993; Marshall et al., 2001; Bentsen et al., 2004; Jungclaus et al., 2005; Medhaug et al., 2011).

At present there is no consensus to what degree the AMOC variability is an ocean-only mode excited by (Frankcombe et al., 2009) or damped by (Hasselmann, 1976; Frankignoul et al., 1997) atmospheric forcing; an ocean-only mode with density fluctuations in the convection regions driven by advection of density anomalies from the south (e.g., Vellinga and $\mathrm{Wu}, 2004)$ or the northern high latitudes (e.g., Delworth et al., 1993); a fully coupled atmosphere-ocean or atmosphere-sea ice-ocean mode with the deep water formation rate dominated by variations in the local wind forcing (e.g., Dickson et al., 1996; Häkkinen, 1999; Eden and Willebrand, 2001; Deshayes and Frankignoul, 2008; Msadek and Frankignoul, 2009; Medhaug et al., 2011).

Low frequency variability in the ocean overturning circulation and possible relations with upper ocean heat content and air-sea interaction of heat and moisture suggest a potential for predicting surface temperature and atmospheric mean state on annual to decadal time scales. Recent works in this rapidly growing research field suggest that AMOC is predictable up to 20 years (Collins et al., 2006). By relaxing the model to observed SSTs (Keenlyside et al., 2008), to upper ocean properties (temperature and salinity) and atmospheric data (Smith et al., 2007), or to hydrographic observations (Pohlmann et al., 2009), the various groups have reported improved prediction skills of both global and regional climate. More precise understanding of the linkages between the hydrographic structure of the ocean, the large scale ocean circulation, and the impacts of variations in the ocean transports on atmospheric climate, will increase our ability to give more realistic decadal forecasts in the years to come.

The temporal resolution of AMOC is sparse, with transatlantic measurements taken only four times during the time period 1957-1997 (Fuglister, 1960; Roemmich and Wunsch, 1985; Parrilla et al., 1994; Baringer and Molinari, 1999), and with continuous measurements only available since 2004 (Cunningham et al., 2007). Due to the extent of the basin- scale circulation long term direct observations of the AMOC have not been conducted as it would require an unrealistic number of sections and instruments. As a result, neither the relationships between the AMO and AMOC in nature, nor the impacts of AMOC on North Atlantic climate variability are known. We therefore have to primarily rely on models in this study. Some previous studies, however, have used observed sub-surface ocean temperature data to identify AMOC fingerprints that could be used as proxies to reconstruct historical AMOC variations, and reveal the AMOCAMO relationship (Zhang, 2007, 2008). The comparison of observational and modelling results suggests that the observed AMOC proxies are in phase with the observed AMO.

Where earlier studies of AMO or AMOC have been restricted to single models or a subset of the available climate models, for the first time the full range of Intergovernmental Panel on Climate Change (IPCC) Fourth Assessment Report (AR4) climate simulations for the 20th century integrations (1850-2000) have been used in a dedicated investigation of the connection between the two variables of North Atlantic multidecadal variability. Our main objectives have been to investigate to what extent (i) the observed AMOC and AMO strength and variability are captured in the climate models, (ii) relationships exist between the two measures of multidecadal climate fluctuations, (iii) any physical mechanisms behind such relationships can be identified, and (iv) century long observations of SST can be used as a proxy for AMOC, and knowledge of the phase of the AMOC therefore will improve our ability to predict climate on interannual to decadal time scales.

Section 2 gives an overview of the modelling and observational data sets used in this study and the applied statistical methods. The results of the model analysis, and comparison with observations, are given in Sect. 3, and the results and their implications discussed in Sect. 4. Section 5 gives a summary with concluding remarks on the implications for predictability of AMO and other climatic variables based on the state of the AMOC.

\section{Methods and data}

\subsection{The coupled models}

This study is based on 24 climate simulations provided by 16 modeling groups worldwide (Table 1). Available monthly mean surface temperature (TS), sea ice concentration (SIC) and Atlantic meridional overturning streamfunction (AMOC) data from the scenario "twentieth century climate in coupled models" (20c3m) are used. For most models the scenario $20 \mathrm{c} 3 \mathrm{~m}$ covers the period $1850-2000$. The models have been integrated using observed values of greenhouse gas concentrations and direct effect of sulphate aerosols. For 12 of the models also natural forcing (volcanic aerosols and solar variability) has been included, and for 13 of the 
Table 1. List of models that participate in this study.

\begin{tabular}{|c|c|c|c|}
\hline Modeling groups & IPCC ID & $\begin{array}{l}\text { Horizontal } \\
\text { Atm. res. }\end{array}$ & $\begin{array}{l}\text { Natural } \\
\text { forcing }\end{array}$ \\
\hline Bjerknes Centre for Climate Research, University of Bergen, Norway & BCCR-BCM2.0 & T63 & No \\
\hline National Center for Atmospheric Research, USA & CCSM3 & T85 & Yes \\
\hline \multirow[t]{2}{*}{ Canadian Centre for Climate Modeling \& Analysis, Canada } & CGCM3.1(T47) & T47 & No \\
\hline & CGCM3.1(T63) & T63 & No \\
\hline Météo-France/Centre National de Recherches Météorologique, France & CNRM-CM3 & T63 & No \\
\hline \multirow{2}{*}{ CSIRO Atmospheric Research, Australia } & CSIRO-Mk3.0 & T63 & No \\
\hline & CSIRO-Mk3.5 & T63 & No \\
\hline Max Planck Institute for Meteorology, Germany & ECHAM5/MPI-OM & T63 & No \\
\hline $\begin{array}{l}\text { Meteorological Institute of the University of Bonn, } \\
\text { Meteorological Research Institute of KMA, } \\
\text { and Model and Data group, Germany/Korea }\end{array}$ & ECHO-G & $\mathrm{T} 30$ & Yes \\
\hline LASG/Institute of Atmospheric Physics, China & FGOALS-g1.0 & $\mathrm{T} 42$ & No \\
\hline \multirow{2}{*}{ NOAA/Geophysical Fluid Dynamics Laboratory, USA } & GFDL-CM2.0 & $2.0^{\circ} \times 2.5^{\circ}$ & Yes \\
\hline & GFDL-CM2.1 & $2.0^{\circ} \times 2.5^{\circ}$ & Yes \\
\hline \multirow[t]{3}{*}{ NASA/Goddard Institute for Space Studies, USA } & GISS-AOM & $3^{\circ} \times 4^{\circ}$ & No \\
\hline & GISS-EH & $4^{\circ} \times 5^{\circ}$ & Yes \\
\hline & GISS-ER & $4^{\circ} \times 5^{\circ}$ & Yes \\
\hline National Institute of Geophysics and Volcanology, Italy & INGV-SXG & T106 & No \\
\hline Institute for Numerical Mathematics, Russia & INM-CM3.0 & $4^{\circ} \times 5^{\circ}$ & Yes \\
\hline Institute Pierre Simon Laplace, France & IPSL-CM4 & $2.5^{\circ} \times 3.8^{\circ}$ & No \\
\hline Center for Climate System Research, National Institute for & MIROC3.2(HI) & T106 & Yes \\
\hline $\begin{array}{l}\text { Environmental Studies, and Frontier Research Center } \\
\text { for Global Change, Japan }\end{array}$ & MIROC3.2(MED) & $\mathrm{T} 42$ & Yes \\
\hline Meteorological Research Institute, Japan & MRI-CGCM2.3.2 & $\mathrm{T} 42$ & Yes \\
\hline National Center for Atmospheric Research, USA & PCM & T42 & Yes \\
\hline \multirow[t]{2}{*}{ Hadley Centre for Climate Prediction and Research/Met Office, UK } & UKMO-HadCM3 & $2.8^{\circ} \times 3.8^{\circ}$ & No \\
\hline & UKMO-HadGEM1 & N96 & Yes \\
\hline
\end{tabular}

models tropospheric and stratospheric ozone. Only four of the models use flux adjustment, CGCM3.1 T47 and T63 (globally), INM-CM3.0 (regionally) and MRI-CGCM2.3.2 (in tropics). The data is the same as used in the IPCC AR4 and is downloaded from the World Climate Research Program's (WCRP's) Coupled Model Intercomparison Project phase 3 (CMIP3) multi-model database.

From the model output the AMO index is defined as the area-weighted SST for $60^{\circ} \mathrm{W}-0^{\circ}, 0^{\circ}-60^{\circ} \mathrm{N}$, similar to definitions used in earlier works (e.g., Knight et al., 2005; Sutton and Hodson, 2005). For the spatial maps of the multi model mean and their spread, all models are interpolated onto a $2.5^{\circ} \times 2.5^{\circ}$ grid using exponential kernel smoothing (Gijbels et al., 1999), where weights are decreasing exponentially with distance from the center point of each grid cell. Data from a distance exceeding $600 \mathrm{~km}$ are excluded from the interpolation. The intermodel standard deviation is used as a measure of the level of agreement between the different models, where the mean has been subtracted for the individual model.
In models the AMOC index is usually defined as the maximum Atlantic meridional overturning streamfunction in a zonal band, either chosen at a specific latitude (usually $30^{\circ} \mathrm{N}$ ) or in a latitude band (e.g., north of $20^{\circ} \mathrm{N}$ ), measured in Sverdrup $\left(1 \mathrm{~Sv}=10^{6} \mathrm{~m}^{3} \mathrm{~s}^{-1}\right)$. Here maximum north of $20^{\circ} \mathrm{N}$ in the annual streamfunction is used. To exclude surface wind driven overturning we have used the further criteria that the maximum should be located deeper than $500 \mathrm{~m}$ (Schott et al., 2004). The meridional stream function is only available for 18 of the models.

The sea ice extent is defined here as the area where the sea ice concentration equals or exceeds $15 \%$. The sea ice is regridded into a $2.5^{\circ} \times 2.5^{\circ}$ grid using the same interpolation method as given above.

\subsection{Observations}

In order to compare the model performance with observations, gridded time series of SST on a $5^{\circ}$ latitude by $5^{\circ}$ longitude grid (Kaplan SST V2, see Kaplan et al., 1998) are used. These time series are provided by the Climate Diagnostics 
Center, Boulder, Colorado, USA, from their Web site at http: //www.cdc.noaa.gov/ on a monthly global field from 1856 to present.

From observations the AMO index is found in the same manner as from models. For AMOC no exact measurements or estimates exists. However, the AMOC strength is a measure of the net northward transport in the upper ocean, or to a good approximation net southward transport at depth (e.g., Ganachaud and Wunsch, 2000; Talley et al., 2003). Due to the Bering Strait through flow (Woodgate et al., 2005) the latter definition is slightly larger than the former.

\subsection{Statistical methods}

A one-sided adaptively weighted multitaper method is used to make power spectral densities for the AMOC and AMO indices (Thompson, 1982). The seasonal cycle and the linear trend in the time series are removed from the monthly values prior to the analysis. The power spectrum of the rednoise spectra is computed from the first order autoregressive (AR(1); e.g., Bartlett, 1966) process for the individual time series.

In order to remove high frequency variability, time series are filtered using a 15 year running binomial filter. Compared to standard running mean this filter to a large extent remove spectral leakage in the filtered time series.

To investigate statistical significance of the lagged correlation (at $5 \%$ level), a two sided t-test has been used with the estimated effective degrees of freedom, $N_{\mathrm{e}}$. This is calculated from the formula of Quenouille (1952); $N_{\mathrm{e}}=N /(1+$ $2 r_{a}^{1} r_{b}^{1}+2 r_{a}^{2} r_{b}^{2}$ ), where $N$ is the number of data points in the time series, $r_{a}^{1}$ and $r_{b}^{1}$ are the autocorrelations at lag one, and $r_{a}^{2}$ and $r_{b}^{2}$ the autocorrelations at lag two for time series $a$ and $b$, respectively.

\section{Simulated AMO and AMOC variability}

\subsection{AMO}

The spatial pattern of the sea surface temperature (SST) field associated with the AMO index is shown in Fig. 1. In the observations there is an overall high positive correlation between the SST and the AMO index for the entire AMO region (shown as square box in the first plot). A region with reduced correlation is seen in the Gulf Stream area and in the Nordic Seas. Most models also show a region of reduced or slightly negative correlation along the North American coast, but for some models this region is shifted slightly north or is distributed over a larger area. Some of the models show polar amplifications of the AMO signal. This is not seen in the observations here due to the lack of data, but has been identified in earlier papers (e.g., Polyakov et al., 2004). Both observations and the majority of models show the strongest correlation between SST and the AMO index in the tropical Atlantic. North of $30^{\circ} \mathrm{N}$ the models are more varying.

The AMO index for the different models are shown in Fig. 2a. The mean of the period 1901-1980 has been removed form the models. FGOALS-g1.0 starts from a relative warm state, in contrast to the other models and observations. The model has yet to reach a stable equilibrium, and the model has therefore been omitted from the ensemble mean in this figure.

The individual models (thin lines) show highly varying amplitudes, but all models do show a warming in the last two decades when anthropogenic warming becomes influential (IPCC, 2007). Compared to the observations (thick yellow line), the ensemble mean (thick black line) shows much less variability. This is to be expected from an average of many independent realizations. For most years the observations are nevertheless reproduced by the model spread, here shown as the 10-90 percentile (gray band). The two main discrepancies between the model spread and the observations are during the mid century warming (1930s-1950s) where the models underestimate the warming, and during the subsequent cold period (1960s-1980s) when the models are generally too warm. This could be due to errors in the observed time series, inadequacy in the modelled response to the external forcing or forcing that is not included in the simulation, or due to timing of the internal/natural variability in the models compared to observations.

Figure $2 \mathrm{~b}$ shows the power spectra for the AMO index. The observations have two bands of increased power, one at multidecadal time scales (above $\sim 30$ years) and one around 10 years, both being above the level of red noise. Due to varying autocorrelation at lag one for the models and observations, the individual red-noise spectra are not shown. The interannual-decadal power maximum in observations is likely the imprint of the North Atlantic Oscillation on the SST, as this atmospheric mode does show enhanced power at these time scales (Furevik et al., 2003; Hurrell et al., 2003). Several studies have suggested that the ocean also feeds back on the atmosphere at these time scales (Kushnir, 1994; Marshall et al., 2001). Most models show maximum power at multidecadal time scales but with too weak amplitudes compared to the observations. Typically the models show more energy at 10-30 years time scales than observations. The observed maximum at around 10 years is not captured by the models.

The persistence in the modelled AMO index, defined as the maximum time lag before the autocorrelation function first crosses the significance line at $5 \%$ level (Fig. 3), varies from 1 and up to 25 years (Table 2). This indicates the potential for predicting future SSTs based on persistence. For the observations the equivalent persistence time scale is 11 years.

In order to check to what extent the models are able to reproduce the observed warming and cooling patterns, composites of 15 warm years minus 15 cold years are made. Since the models are not able to reproduce the timing of the 

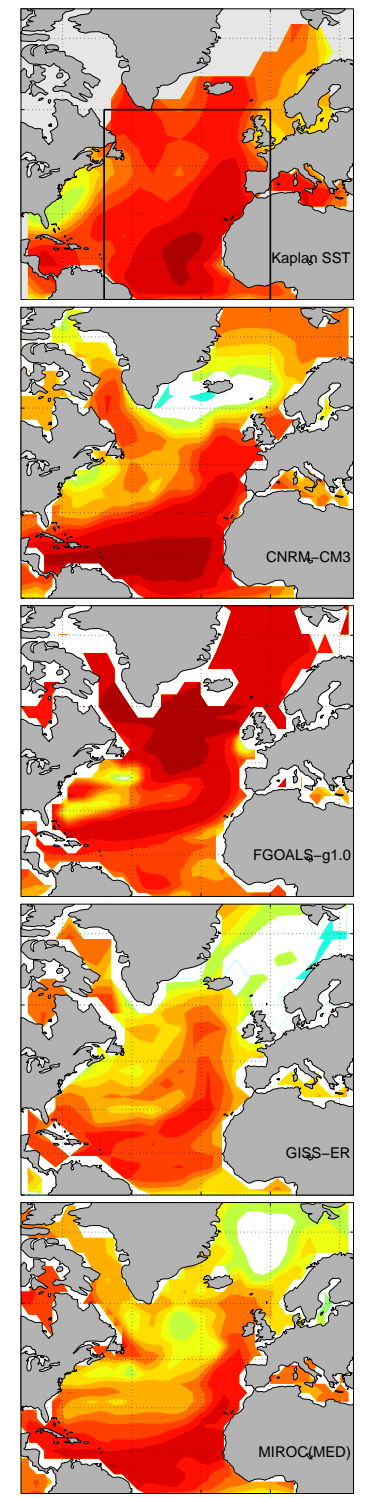
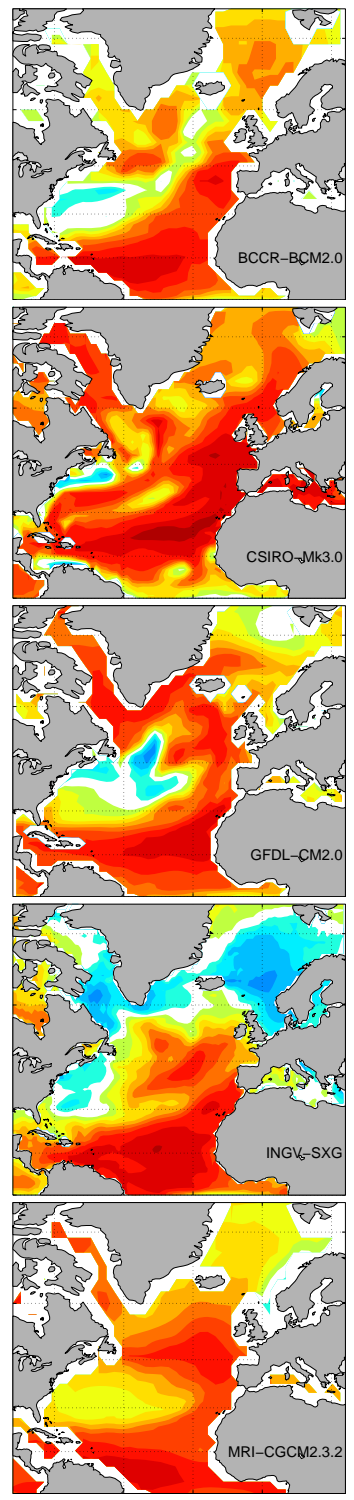
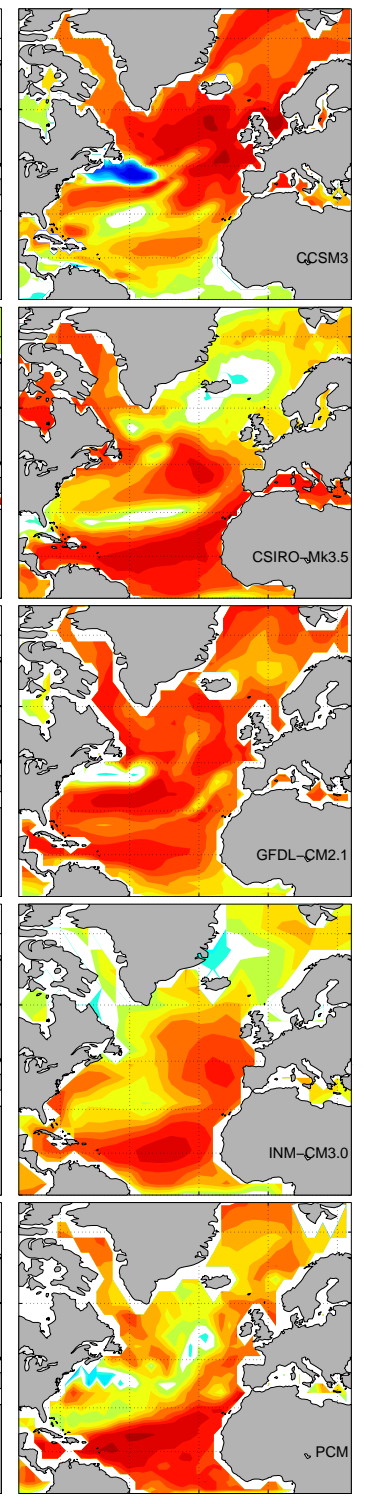

$-0.5$

0

0.5
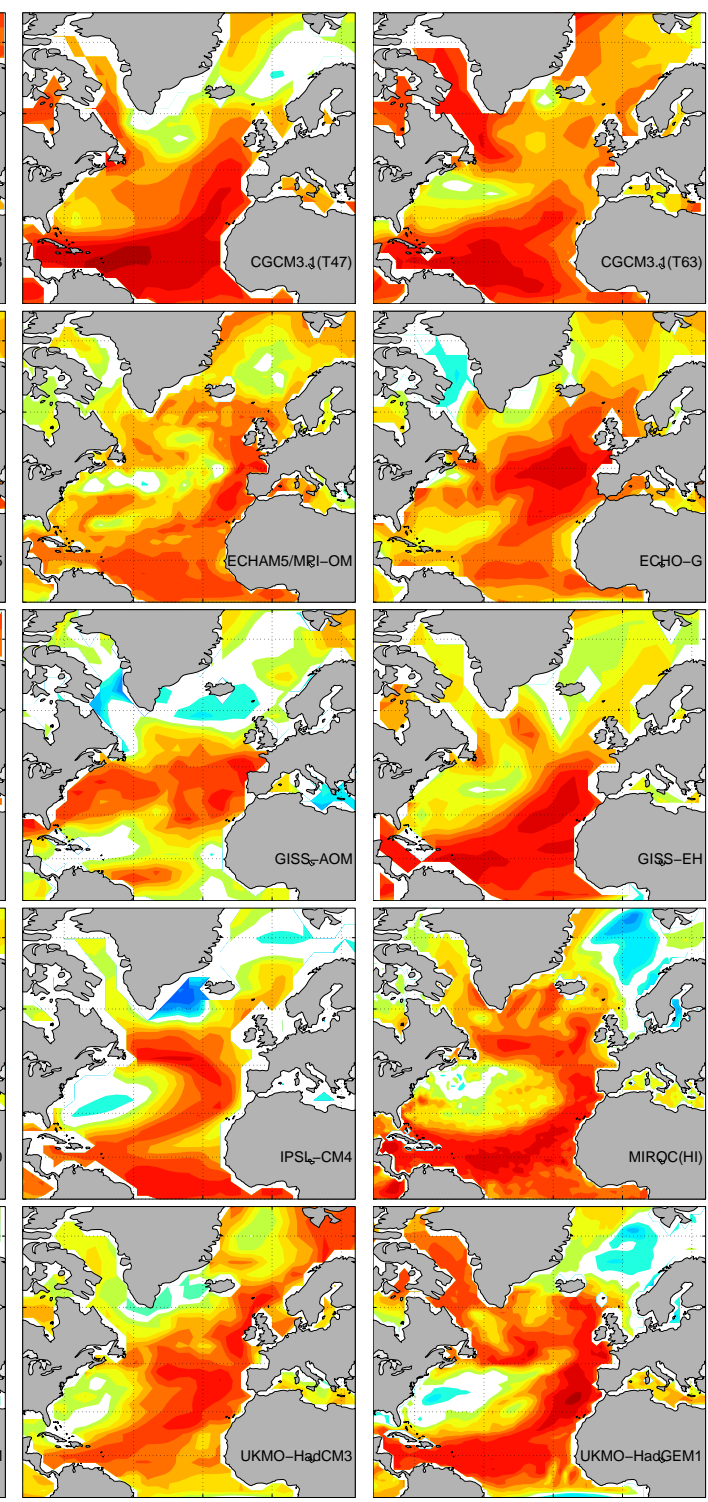

$-1$

Fig. 1. The correlation between the local SST and the AMO index in the observations (upper left panel) and in the 24 models. The gray shading over ocean means too few observations. The AMO is defined as the average SST inside the black box shown in the first plot. The time series are filtered with a 15 year running binomial filter to remove the high frequency variability and the linear trends are removed prior to the correlation.

observed extremes, the simulated warm periods have been selected where the 15 year average temperature in each simulation is at its maximum, and the subsequent modelled cold period is then subtracted (Table 2). Due to the anthropogenic warming signal adding to the amplitude of the SST variability towards the end of the time series, warm periods after 1980 have been omitted. FGOALS-g1.0 does not have any distinct warm or cold 15 year periods, hence it is omitted from the ensemble. The ensemble mean patterns of the warm and cold periods are statistically different with regards to the $5 \%$ level in a two sided t-test, except for in the Nordic Seas, south of $\sim 10^{\circ} \mathrm{N}$ and in the Gulf Stream region. Here, the number of models are used as degrees of freedom. The difference between the composites (Fig. 4a) has the same sign in the whole North Atlantic with largest values in the Subpolar Gyre region to the southeast of Greenland. A warm tongue is also seen extending from the Nordic Seas and into the Barents Sea. The intermodel spread (thin black lines) roughly 

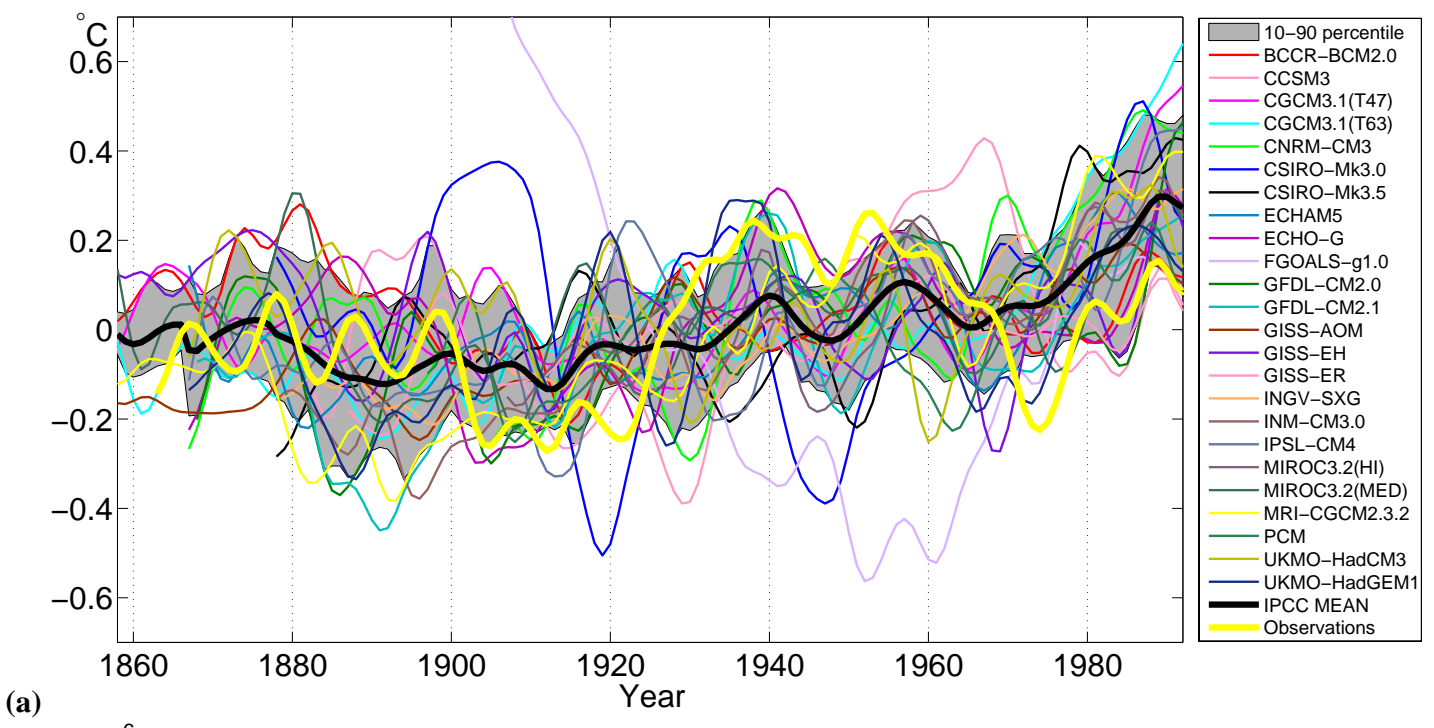

(a)

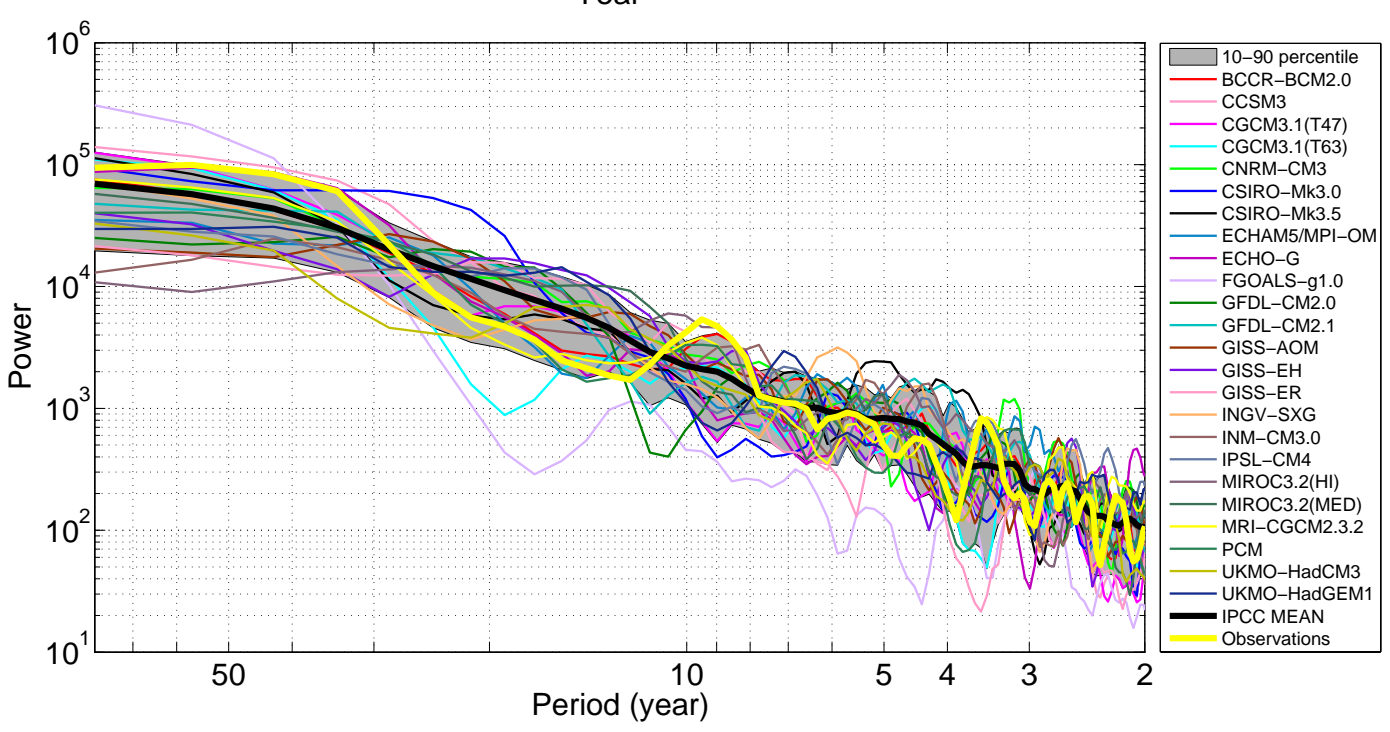

(b)

Fig. 2. (a) The annual mean AMO index in the different models (thin lines) and observations (thick yellow line) relative to the mean of 1901-1980. The black thick line shows the ensemble mean and the gray band shows the 10-90 percentile of the model spread. All curves are filtered by a 15 year running binomial filter. The units are given in ${ }^{\circ} \mathrm{C}$. (b) Smoothed power spectrum of the monthly mean AMO. The linear trends are removed and the time series are standardized for different models prior to the analysis. The colours are the same as in (a).

follows the pattern of the anomaly. The largest model spread is found in the Subpolar Gyre region including the Irminger Sea, with almost the same amplitude as the differences between the warm and cold composites. In the tropical Atlantic there is only marginally higher temperatures in the warm compared to the cold periods. In order to see how sensitive this signal is to the chosen warm and cold periods, differences between all warm minus all cold 15 year periods in the models have also been calculated. This analysis gives approximately the same results (not shown).

The observed SST difference between a warm (19411955) and a cold (1967-1981) 15 year period (Fig. 4b) shows a warm anomaly mainly focused in the center of the Subpolar Gyre and around Iceland. The year to year standard deviation of the observed time series (thin black lines) shows that most of the temperature variance is found in the regions of largest temperature differences. The choice of warm period in the observations could potentially be problematic due to changes in the sampling technique (Thompson et al., 2008). Changing from warm biased engine room intake measurements (US ships) to a temporary majority of uninsulated bucket measurement (UK ships) may have made the cooling trend in the data larger than in reality. To test the robustness of the results, we have shifted the period forward or backward in time. The pattern stays the same but with a slightly reduced amplitude when omitting most of the affected time period (not shown). Comparison with the models show that the regions with largest temperature differences are south of Greenland 


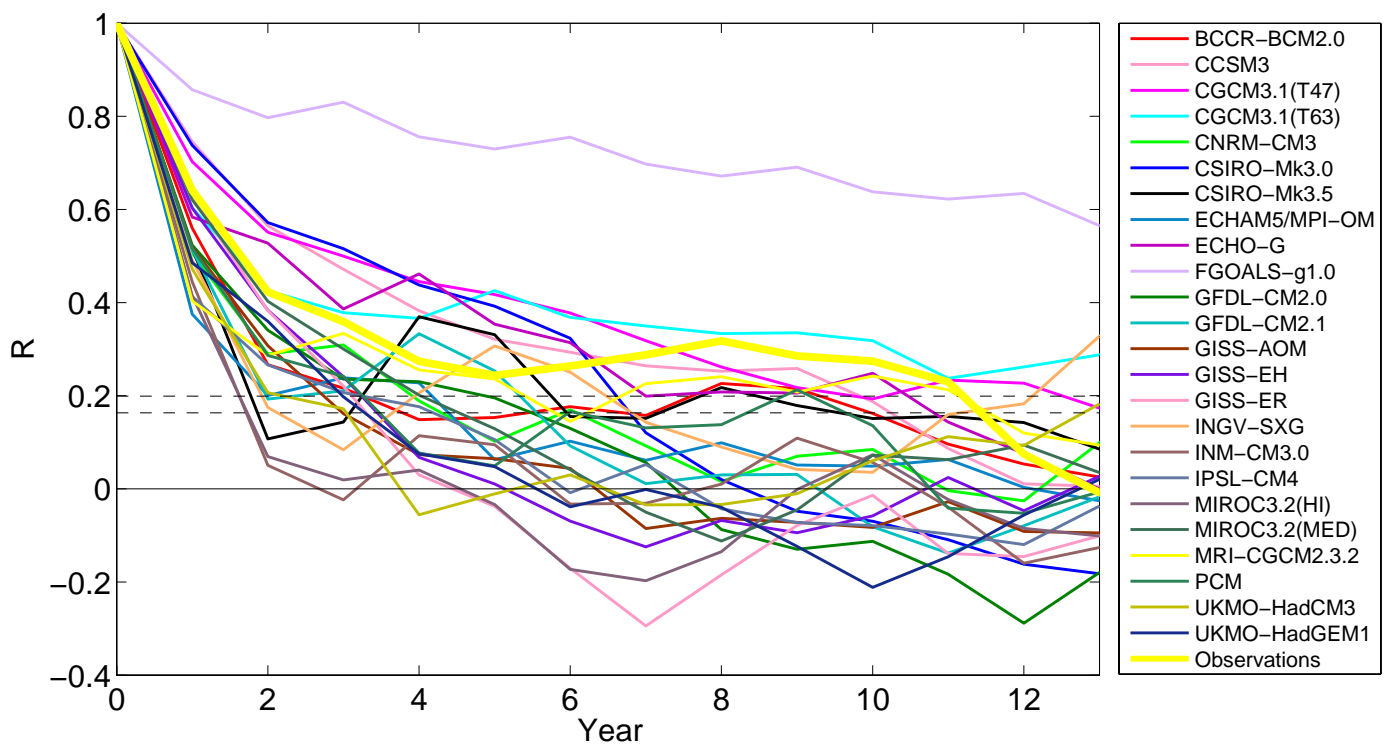

Fig. 3. Autocorrelation function for the annual mean values of the AMO index in the different models (thin coloured lines), and for the observations (thick yellow line) to estimate the persistence in the time series. Significance level varies between the two dashed black lines, depending on length of the time series.

(a)

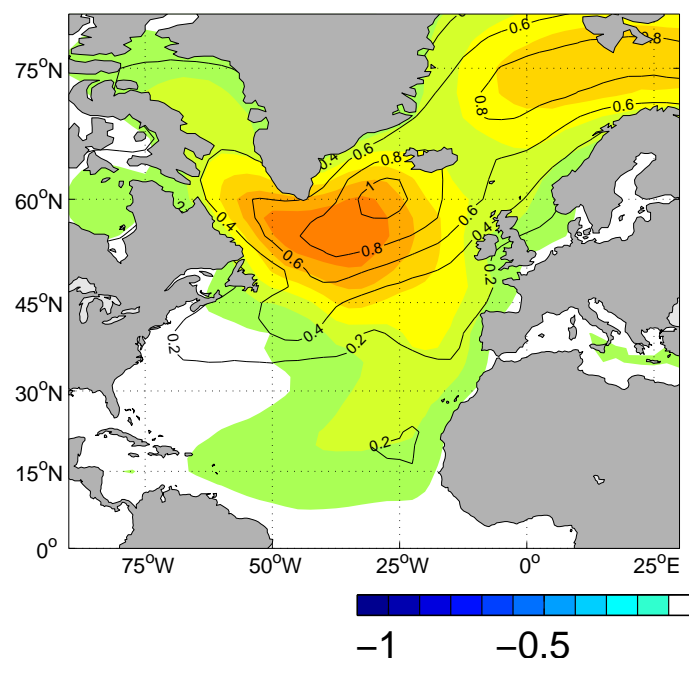

(b)

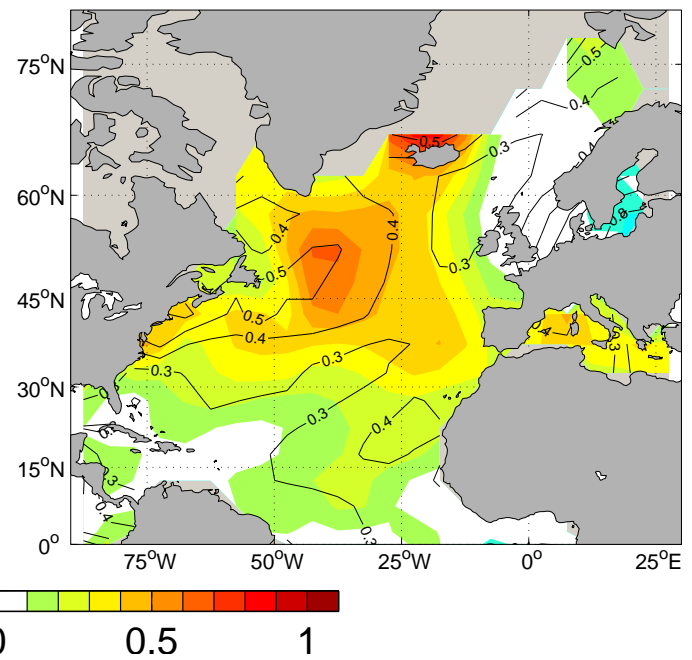

Fig. 4. (a) Colour shading shows mean SST difference between the warmest 15 year period and the subsequent cold 15 year period in the models (see Table 2). Thin black lines show spread in the warm minus the cold SST differences represented by the standard deviation of the model responses. (b) Observed SST difference $\left({ }^{\circ} \mathrm{C}\right)$ between a warm 15 year period (1941-1955) and the subsequent cold 15 year period (1967-1981). Thin black lines indicate the variability, given by the year to year standard deviation in of the observed time series. Gray areas have too few observations to make the analysis. Observations are from Kaplan et al. (1998).

for both cases, but over a slightly larger region in the observations. In the Norwegian Sea a modest warm anomaly is found in the models but not in the observations, while in the Iceland Sea the anomaly in the models is too low compared to the observations.

\subsection{AMOC}

The models show highly varying structures in the mean state of their overturning (Fig. 5). The positions of the maximum overturning are typically found at $600-1500 \mathrm{~m}$ depth and between $20^{\circ} \mathrm{N}$ and $60^{\circ} \mathrm{N}$. In comparison, the estimated 

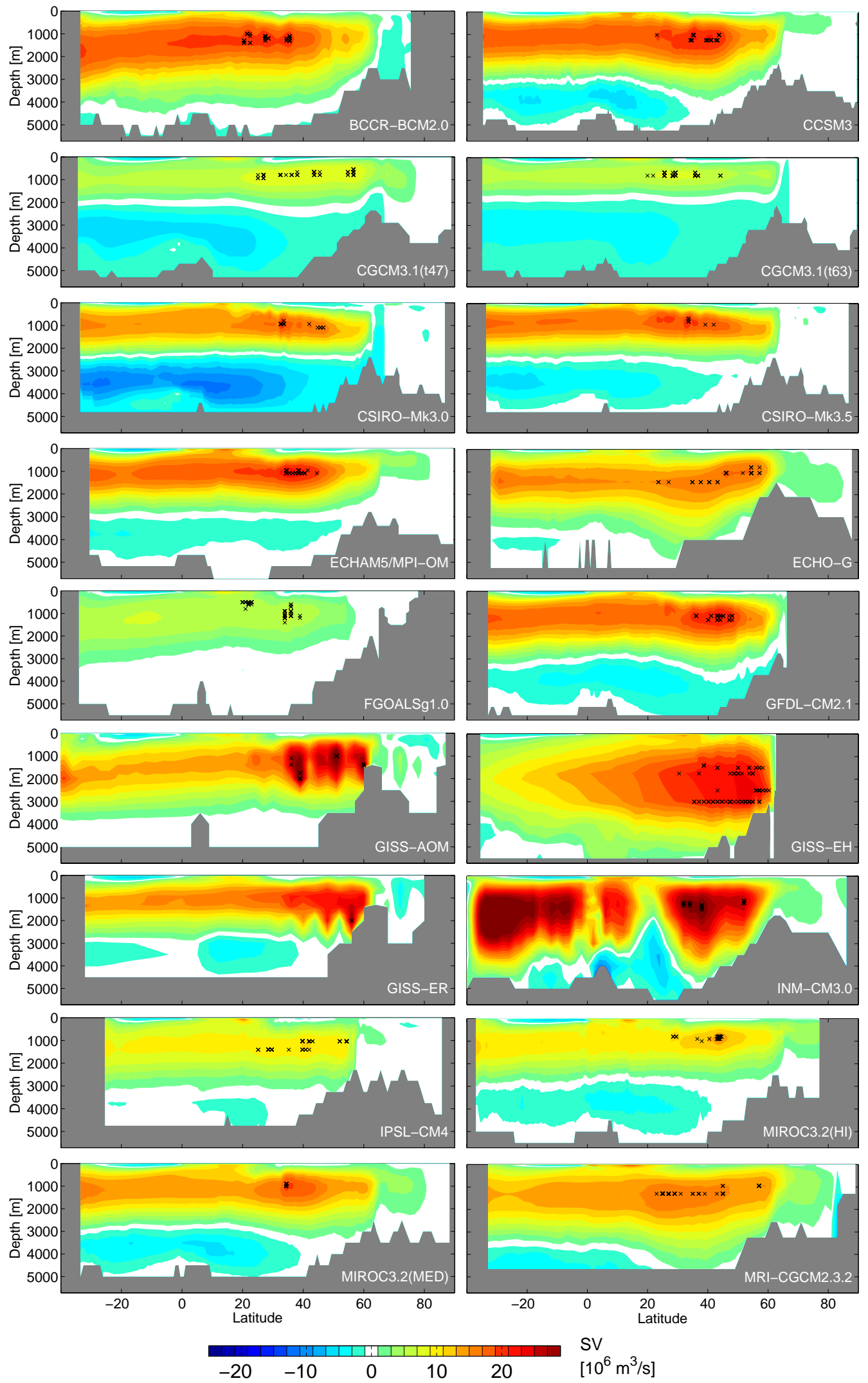

Fig. 5. Mean state of the Atlantic meridional overturning streamfunction for the different models. Colour shading represents volume transport $\left(\mathrm{Sv}=10^{6} \mathrm{~m}^{3} \mathrm{~s}^{-1}\right)$, where positive (negative) values indicate a clockwise (anticlockwise) circulation. $\times$ mark location of maximum overturning north of $20^{\circ} \mathrm{N}$ for individual years in the model. 

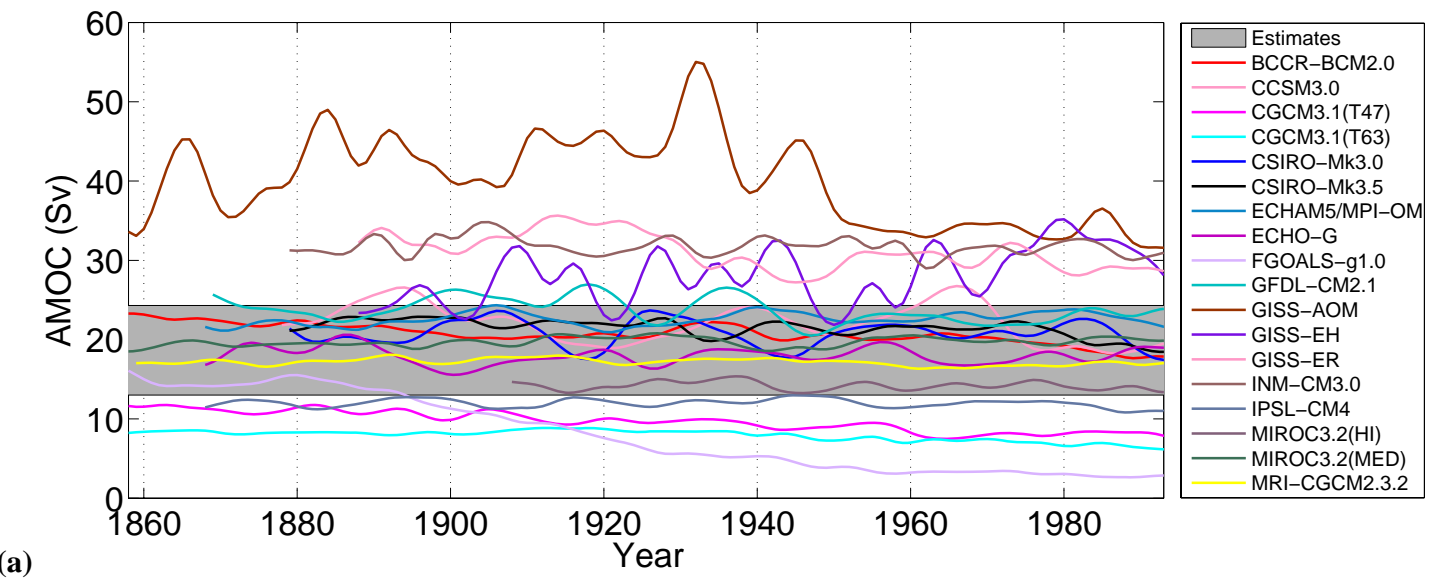

(a)
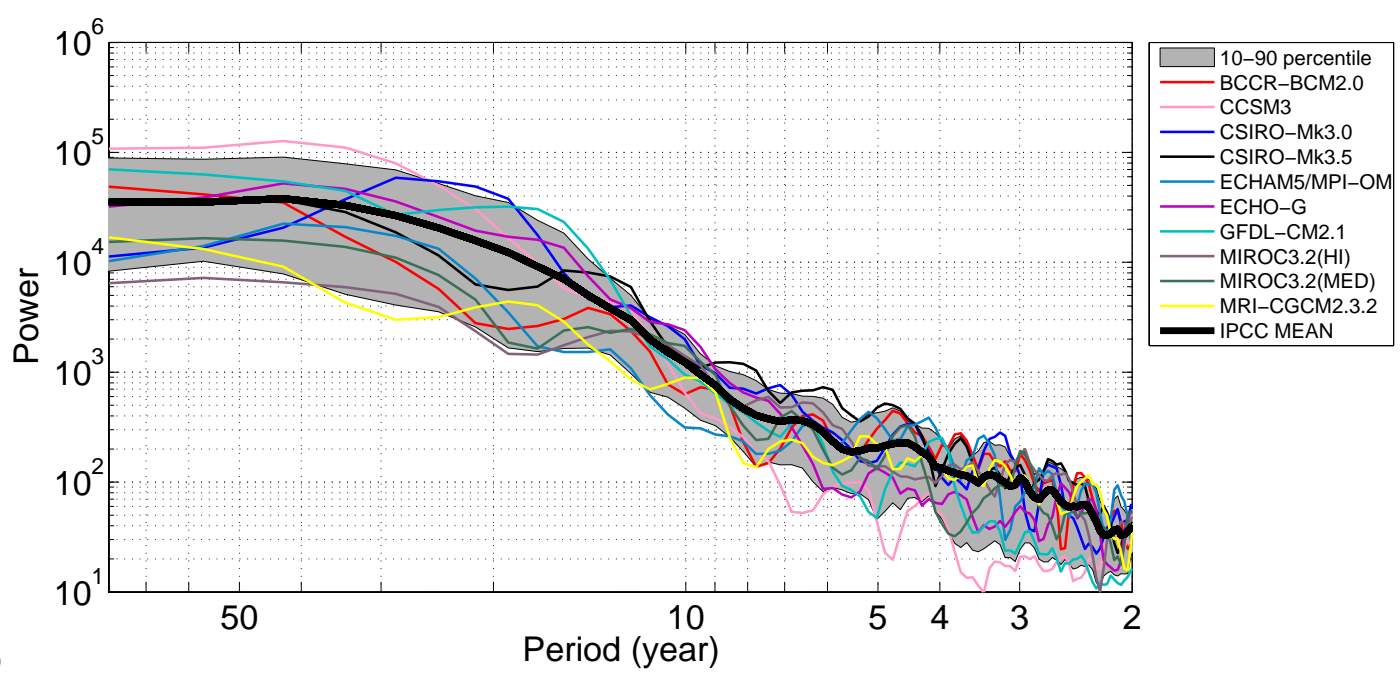

Fig. 6. (a) Atlantic Meridional Overturning Circulation (AMOC) strength (in $\mathrm{Sv}=10^{6} \mathrm{~m}^{3} \mathrm{~s}^{-1}$ ) for the individual model, defined as the maximum in the annual meridional streamfunction north of $20^{\circ} \mathrm{N}$ and below $500 \mathrm{~m}$ depth. All curves are filtered by a 15 year running binomial filter. The gray band shows the present-day observational estimates of the AMOC in the range 13-24.3 Sv (references in text). (b) Smoothed power spectrum of the detrended monthly time series of AMOC strength. The linear trends are removed and the time series are standardized for the different models prior to the analysis. The gray band shows the 10-90 percentile of the model spread, where the thick black line is the model mean and the coloured lines are the same as in (a). Only the 10 models having a mean overturning within the observed range are shown.

depth of the maximum overturning at $25^{\circ} \mathrm{N}$ is from observations around $1000 \mathrm{~m}$ (Bryden et al., 2005). There are large differences in how the models reproduce the lower overturning cell. Several models show either an absent or a very weak lower overturning cell of Antarctic Bottom Water (AABW), while other models show AABW all the way north to $60^{\circ} \mathrm{N}$. Hydrographic observations show that the AABW has almost disappeared north of $35^{\circ} \mathrm{N}$ (Johnson, 2008). One model, INM-CM3.0, show a deep gyre-driven upper circulation where the subtropical and subpolar gyres are nearly decoupled and where the AABW cell seems to be disconnected from the regions of $\mathrm{AABW}$ formation.

The models show an annual mean overturning circulation range from 1.3 to $67.7 \mathrm{~Sv}$, with a long term mean between 7.6 and 39.6 Sv. Based on hydrography, present-day estimates of the AMOC strength are $14-18 \mathrm{~Sv}$ at $24^{\circ} \mathrm{N}$ (Ganachaud and
Wunsch, 2000; Lumpkin and Speer, 2003) and 13-19 Sv at $48^{\circ} \mathrm{N}$ (Ganachaud, 2003). Average values from estimates of NADW formation rate are 17.2 Sv (Smethie and Fine, 2001) and $18 \mathrm{~Sv}$ (Talley et al., 2003) with an error of $\pm 3-5 \mathrm{~Sv}$. Observations from hydrographic sections at $26.5^{\circ} \mathrm{N}$ measured in the period 2004-2005, show year-long average overturning of $18.7 \pm 5.6 \mathrm{~Sv}$ (Cunningham et al., 2007). Taking all the observations together, this gives an observed range of 1324.3 Sv. Many models are outside these estimates (Fig. 6a). GISS-AOM, INM-CM3.0, GISS-ER and GISS-EH show too strong, while FGOALS-g1.0, CGCM3.1(T47 and T63) and IPSL-CM4 show too weak overturning compared to the observations. The remaining 10 of the 18 models have a mean overturning within the observed range, and we will focus on this subset of models in the subsequent analysis. 
Table 2. Warm and subsequent cold 15 year periods (center years) used to make AMO composites. The persistence ( $\tau$ given in years) of the AMO time series is taken from the autocorrelation function of the annual time series.

\begin{tabular}{lccr}
\hline Model & Warm & Cold & $\tau$ \\
\hline BCCR-BCM2.0 & 1879 & 1918 & 3 \\
CCSM3 & 1962 & 1980 & 10 \\
CGCM3.1(T47) & 1864 & 1879 & 13 \\
CGCM3.1(T63) & 1923 & 1943 & 13 \\
CNRM-CM3 & 1943 & 1958 & 4 \\
CSIRO-Mk3.0 & 1904 & 1919 & 6 \\
CSIRO-Mk3.5 & 1921 & 1937 & 1 \\
ECHAM5/MPI-OM & 1946 & 1966 & 4 \\
ECHO-G & 1945 & 1975 & 10 \\
FGOALS-g1.0 & - & - & 25 \\
GFDL-CM2.0 & 1960 & 1979 & 5 \\
GFDL-CM2.1 & 1936 & 1950 & 5 \\
GISS-AOM & 1958 & 1968 & 2 \\
GISS-EH & 1878 & 1888 & 3 \\
GISS-ER & 1956 & 1977 & 3 \\
INGV-SXG & 1924 & 1932 & 2 \\
INM-CM3.0 & 1957 & 1968 & 1 \\
IPSL-CM4 & 1925 & 1940 & 4 \\
MIROC3.2(HI) & 1962 & 1970 & 1 \\
MIROC3.2(MED) & 1876 & 1893 & 4 \\
MRI-CGCM2.3.2 & 1956 & 1969 & 5 \\
PCM & 1940 & 1962 & 3 \\
UKMO-HadCM3 & 1878 & 1897 & 3 \\
UKMO-HadGEM1 & 1940 & 1969 & 3 \\
\hline Observations & 1948 & 1974 & 11 \\
\hline
\end{tabular}

Figure $6 \mathrm{~b}$ shows the power spectra for the monthly AMOC index time series. The models have in general most energy on multidecadal time scales. The individual models all show increased power on time scales from around 20 years and upwards. Most models have maximum energy around the red noise level (not shown due to the varying autocorrelation at lag one defined in Sect. 2), but some show a decrease in power for periods from around 30 years and longer.

For the individual models the persistence in the AMOC variability varies from 1 to 10 years (Table 3), defined as the maximum time lag before the autocorrelation function first crosses the significance line at the $5 \%$ level (Fig. 7).

\subsection{Surface response to AMOC variability}

Figure 8a shows the spatial pattern for the ensemble-mean surface temperature (TS) difference composite for a strong 15 year period minus a weak 15 year period of the AMOC index (see Table 3). The periods are selected where the 15 year average AMOC strength is at a maximum and the subsequent period of low AMOC strength subtracted. An exception has been made if the time series start from or end
Table 3. Strong and subsequent weak 15 year periods (center years) used to make AMOC composites. The persistence ( $\tau$ given in years) of the AMOC time series is taken from the autocorrelation function of the annual time series.

\begin{tabular}{llrr}
\hline Model & Strong & Weak & $\tau$ \\
\hline BCCR-BCM2.0 & 1933 & 1949 & 10 \\
CCSM3 & 1891 & 1920 & 8 \\
CSIRO-Mk3.0 & 1905 & 1915 & 4 \\
CSIRO-Mk3.5 & 1891 & 1938 & 5 \\
ECHAM5/MPI-OM & 1905 & 1923 & 7 \\
ECHO-G & 1881 & 1902 & 4 \\
GFDL-CM2.1 & 1903 & 1927 & 5 \\
MIROC3.2(HI) & 1933 & 1948 & 2 \\
MIROC3.2(MED) & 1921 & 1945 & 4 \\
MRI-CGCM2.3.2 & 1911 & 1924 & 1 \\
\hline
\end{tabular}

with the strong or weak AMOC, respectively, since it is unclear whether this is the actual maximum/minimum of the period. For strong AMOC the temperature in the northern North Atlantic and central Nordic Seas is reaching $0.9^{\circ} \mathrm{C}$ higher than for weak AMOC. Compared to the magnitude found for warm minus cold phases of AMO in the Subpolar Gyre region (Fig. 4a), the AMOC composite has a larger temperature difference, and the region of maximum temperature response is slightly displaced northeastward. In the Nordic Seas there is a substantial difference between the AMO and AMOC composites. Only for the tropical Atlantic, weak or even negative temperature differences are found for strong minus weak AMOC. The intermodel spread is very large over Iceland and Denmark Strait and into the Nordic Seas, and the signal to noise ration is low in these areas. The model spread seems to be partly due to the very variable sea ice extent in the different models, where some models have sea ice and others do not in these areas.

The corresponding fractional annual sea ice difference composite is shown in Fig. 8b. The sea ice generally extends further to the south and has higher concentration both in the Nordic Seas and Labrador Sea when AMOC is weak. For individual models the sea ice extent in the Greenland Sea is mainly unchanged or decreased for strong AMOC and increased sea ice extent for weak AMOC compared to the mean (not shown). In the Barents Sea all models show increased sea ice extent for a weak AMOC, while the results are not conclusive for a strong AMOC since some models actually show more than average sea ice also here. For these models, smallest sea ice extent was found for more neutral AMOC states. In the Labrador Sea the models show diverging results, as some models show largest sea ice extent for strong AMOC, others for weak. The models with less sea ice are the same models that show higher temperatures for strong compared to weak AMOC. 
Table 4. Maximum lagged correlation $\left(R_{\max }\right)$ between AMOC and AMO (AMO), and AMOC and rate-of-change of AMO (AMOroc) for the 15 year filtered time series. P-value indicate on which level the correlation is significant, where 0.05 indicates significance at $5 \%$ level using a two sided t-test with correction for degrees of freedom after the method of Quenouille (1952). Lag indicates time lags in years for maximum correlation. Lags are positive when AMOC is leading AMO. Max lag $(N)$ is limited to $20 \%$ of the length of the time series in the individual models.

\begin{tabular}{lcrrrrrr}
\hline & AMO & \multicolumn{3}{c}{ AMOroc } & & $N$ \\
Model & $R_{\max }$ & p-value & Lag & $R_{\max }$ & p-value & Lag & \\
\hline BCCR-BCM2.0 & 0.45 & 0.02 & 21 & 0.29 & 0.07 & -10 & 29 \\
CCSM3 & 0.81 & $<0.01$ & 2 & 0.37 & 0.05 & -4 & 25 \\
CSIRO-Mk3.0 & 0.68 & $<0.01$ & 4 & 0.78 & $<0.01$ & -2 & 25 \\
CSIRO-Mk3.5 & 0.37 & 0.06 & 18 & 0.34 & 0.05 & 15 & 25 \\
ECHAM5/MPI-OM & 0.34 & 0.07 & 3 & 0.35 & 0.04 & -3 & 25 \\
ECHO-G & 0.65 & $<0.01$ & 1 & 0.61 & $<0.01$ & -3 & 27 \\
GFDL-CM2.1 & 0.58 & $<0.01$ & 5 & 0.54 & $<0.01$ & -1 & 19 \\
MIROC3.2(HI) & 0.43 & 0.06 & 4 & 0.43 & 0.04 & 1 & 29 \\
MIROC3.2(MED) & 0.39 & 0.03 & $28^{*}$ & 0.28 & 0.09 & 13 & 28 \\
MRI-CGCM2.3.2 & 0.04 & 0.82 & 7 & 0.28 & 0.09 & 4 & 28 \\
\hline
\end{tabular}

* The peak is located outside of the maximum lag included in the analysis. $R_{\max }=0.4$ at lag 29 .

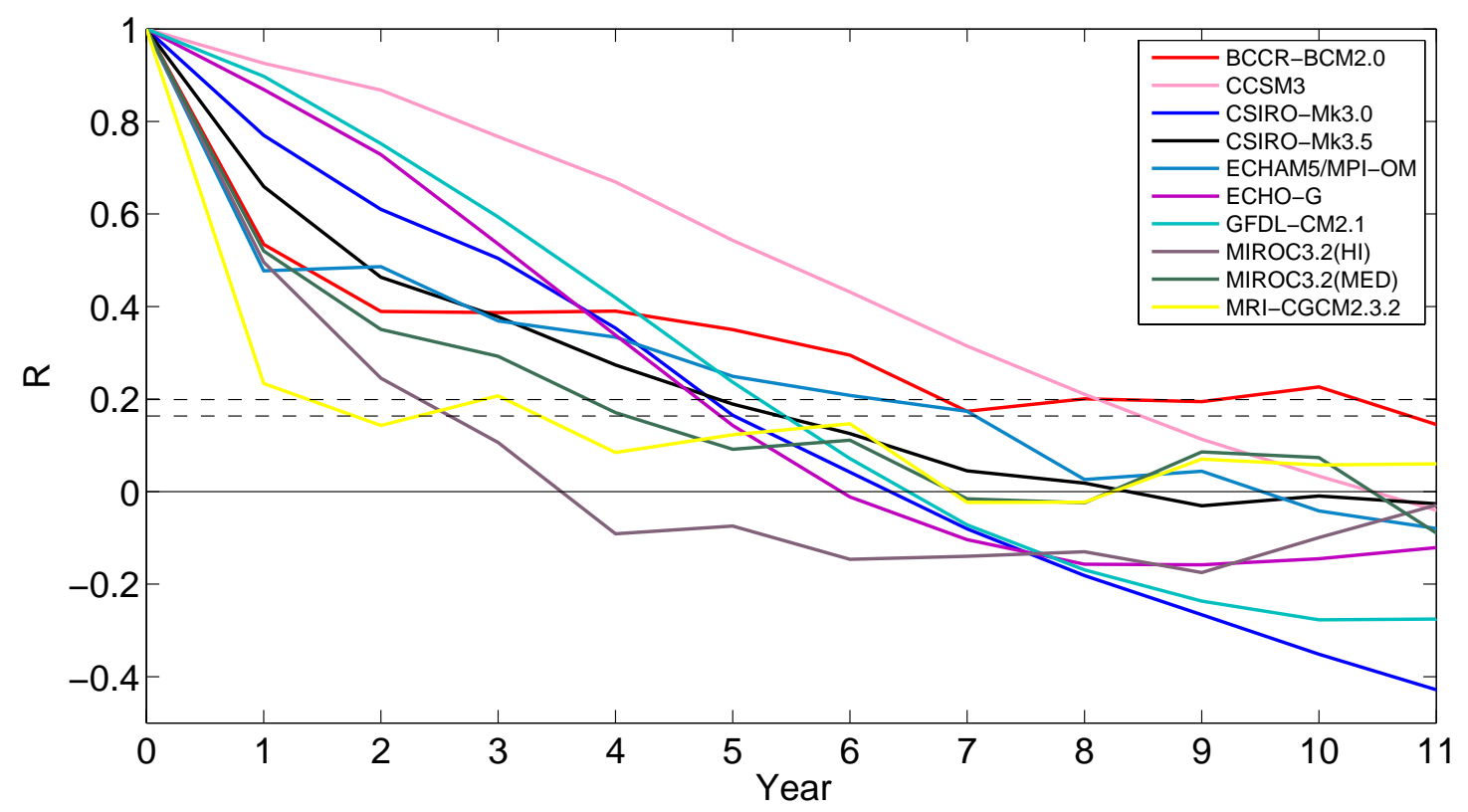

Fig. 7. Autocorrelation function for the annual values of AMOC in the different models (coloured lines). Significance level varies between the two dashed black lines, depending on length of the time series. Only the 10 models having a mean overturning within the observed range are shown.

\subsection{Covariance between AMOC and AMO in models}

The low pass filtered and linearly detrended annual mean time series for the AMOC and AMO indices are shown in Fig. 9. The values and lags for the maximum correlations between the time series are shown in Table 4. Positive lag indicates that $\mathrm{AMOC}$ is leading the $\mathrm{AMO}$, e.g., after a strong
AMOC the North Atlantic SSTs will tend to be high some years later. All models show the maximum correlation at positive lag. The time lags vary between 1 and 29 years, and the correlations vary between 0.04 (not significant) and 0.81 . Thus the maximum variance that can be explained by the covariance is in the order of $65 \%$ or less. 
(a)

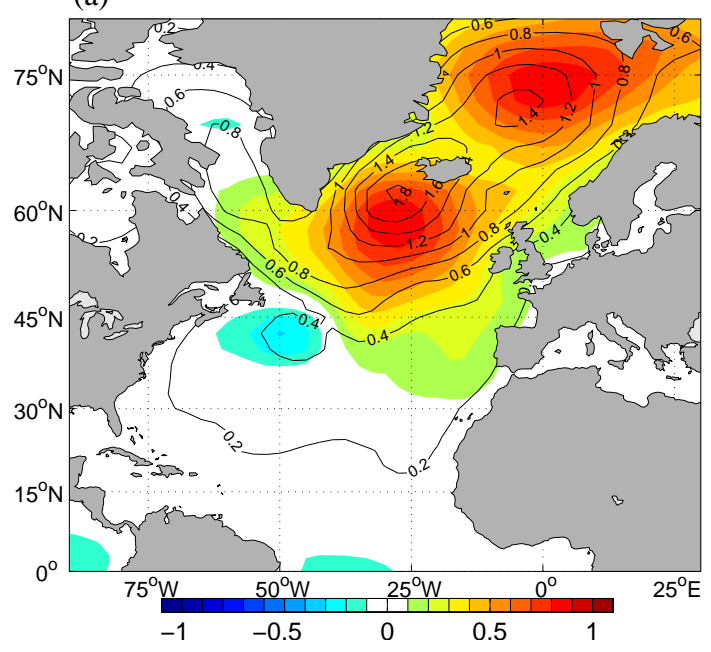

(b)

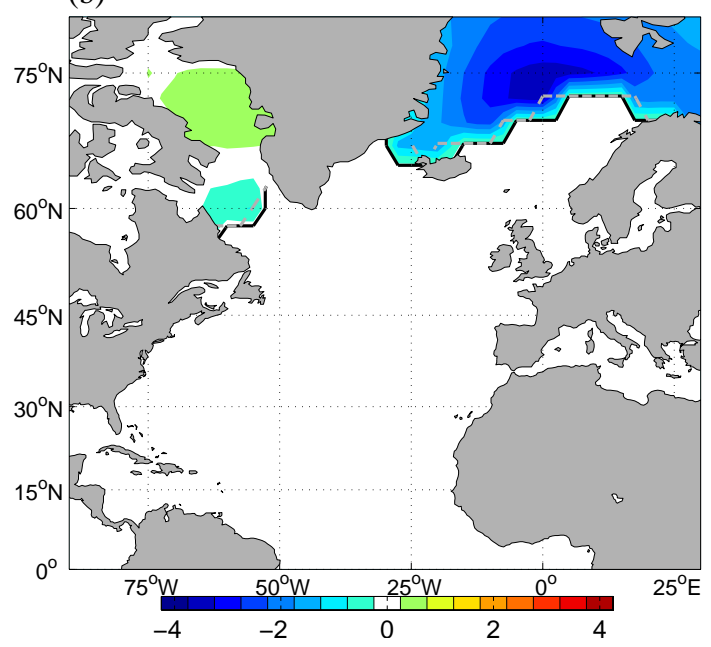

Fig. 8. Composite of the ensemble mean difference between a 15 year period of strong AMOC and a 15 year period of weak AMOC (see Table 3) in (a) surface temperature (colour; ${ }^{\circ} \mathrm{C}$ ), where thin lines show the ensemble standard deviation and (b) the sea ice concentration $(\%)$. The boundary of the annual mean, model-averaged, sea ice extent (defined at $15 \%$ ice concentration) is indicated by the black thick line for the weak AMOC period and thick gray dashed line for the strong AMOC period.

Assuming that the North Atlantic becomes warmer when AMOC is stronger than normal, and colder when AMOC is weak, the rate-of-change of AMO should be a better proxy for AMOC than the actual magnitude of the AMO index itself (Fig. 10). With three exceptions (BCCR-BCM2.0, CSIRO-Mk3.5, MIROC3.2(MED)), the analysis does show that AMOC and rate-of-change of AMO is closer to be in phase (Table 4), indicating that there is a linkage between AMOC strength and warming or cooling of the Atlantic surface waters.

\section{Discussion}

A number of observational studies have shown multidecadal variability in the North Atlantic climate, with a typical time scale of around 50-70 years (e.g., Kushnir, 1994; Schlesinger and Ramankutty, 1994; Delworth and Mann, 2000; Kravtsov and Spannagle, 2008), and a polar amplification of the climate variations (Furevik, 2001; Polyakov et al., 2004). 20th century extremes are the so-called early warming signal in the 1930s-1950s (Delworth and Knutson, 2000) followed by the colder 1960s-1980s, and also the very strong North Atlantic and Arctic warming after the 1990s may partly be due to a positive phasing of this mode (e.g., Knight et al., 2005; Zhang et al., 2007; Knight, 2009). Although many of the climate models are able to give reasonable amplitudes and to some extent the durations of the climate fluctuations in the North Atlantic region, they are not able to reproduce the timing of the observed warm and cold periods in our analysis. This indicates that the variability is intrinsic to the climate system and not primarily externally forced. This is in agreement with the findings of Kravtsov and Spannagle (2008), Knight (2009) and Ting et al. (2009), where a subset of the IPCC AR4 models was analysed. Other possibilities for the discrepancies, such as errors in the observed time series, inadequacy in the modelled response to the external forcing or forcing that is not included in the simulations have been studied thoroughly in Knight (2009), hence will not be discussed here. Other model simulations, on the other hand, indicate that both solar variability and volcanoes play a role in setting the phase of the variability (Hansen et al., 2005; Ottera et al., 2010). The models are in general able to reproduce the pattern of the recent surface temperature extremes in most of the North Atlantic, but amplitudes seem to be too small in the Iceland Sea and too large in the Norwegian Sea compared to observations. Comparing warm minus cold AMO state, there is no sign of the observed polar amplification in the models. This indicates that the polar amplification is not in phase with the AMO.

For strong AMOC, the multi-model ensemble mean shows anomalously high temperatures in the mid and high latitudes (Fig. 8a), and also lower than normal sea ice extent in the Arctic (Fig. 8b). The most plausible mechanism supported by most models is that a stronger overturning transports more oceanic heat to high latitudes where more of the sea ice melts (Delworth et al., 1993; Medhaug et al., 2011). Contradicting this, some models surprisingly show more sea ice for stronger AMOC. An underlying mechanism in this seems to be that more northerly winds over the convection regions move the sea ice edge towards south by advection or local freezing, and more dense water is formed due to cooling and 

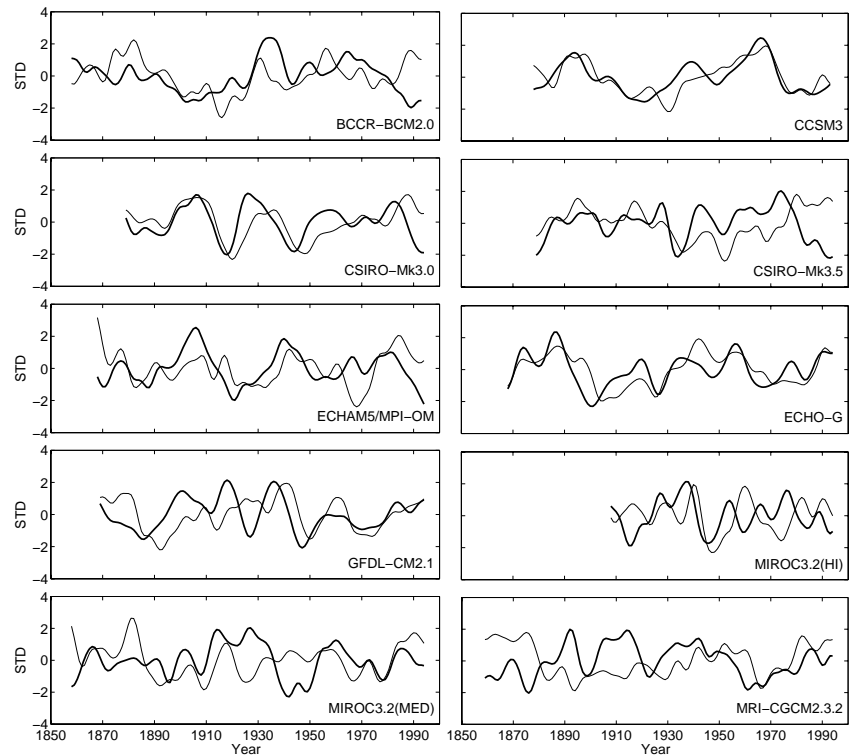

Fig. 9. Normalized AMOC strength (thick line) and AMO (thin line) from the 15 year filtered time series for the different models.
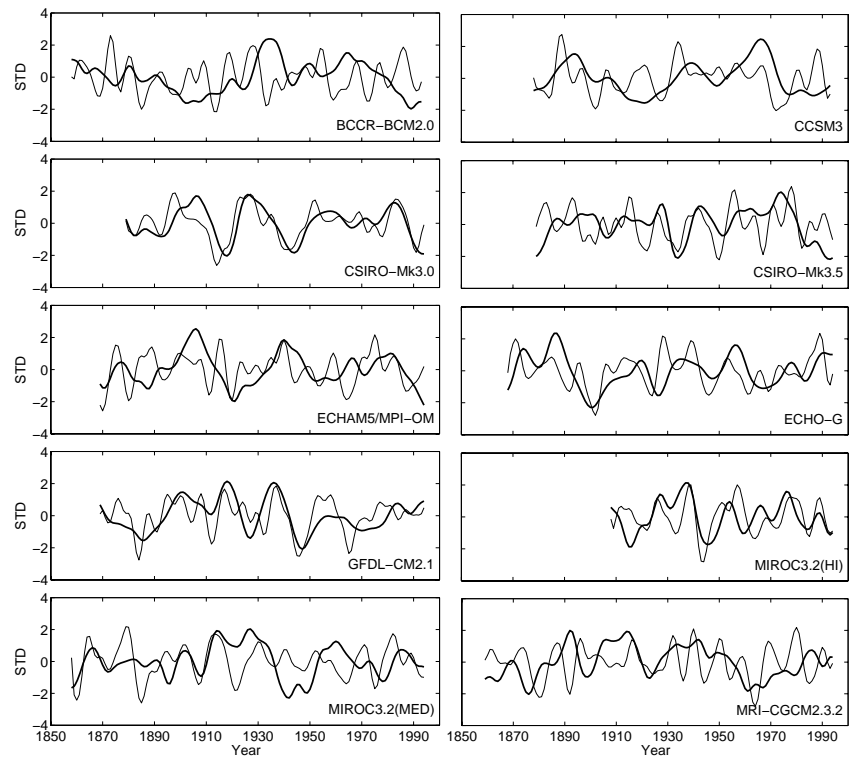

Fig. 10. Normalized AMOC strength (thick line) and AMO rateof-change (thin line) from the 15 year filtered time series for the different models.

possibly also brine release. This will consequently lead to a strengthening of the overturning circulation (Hawkins and Sutton, 2007). The various mechanisms taking place in the individual models have not been the focus of this study and will not be discussed further.

Both the simulated and observed AMO indicate a potential for decadal predictability. While the observations show an inherent AMO persistence of around 11 years, the models have a memory of 1-25 years (Fig. 3). A similar range is found for the modelled AMOC variability, although long persistence of a signal in one parameter does not necessarily imply the same in the other of the two indices of North Atlantic variability. All models are found to have maximum correlation when AMO is lagging AMOC, with lags varying in the range of 1 to 29 years, indicating that AMO variability might be a response to the AMOC variability. When AMOC is found to lead AMO by several decades, an outof-phase relationship between AMO and AMOC may be expected at shorter lags. This is only found for CSIROMk3.5. For the others such relations are not found due to quasi-periodic time series. In 7 out of 10 models, AMOC is in phase with the rate-of-change of AMO, indicating that through changes in the northward advection of ocean heat, the sea surface temperature starts to respond. The overall results are the same whether we are using the AMO definition of Latif et al. (2004) $\left(50-10^{\circ} \mathrm{W}, 40-60^{\circ} \mathrm{N}\right)$, Sutton and Hodson (2005) $\left(75-7.5^{\circ} \mathrm{W}, 0-60^{\circ} \mathrm{N}\right)$ or the dipole pattern from Keenlyside et al. (2008) $\left(60-10^{\circ} \mathrm{W}, 40-60^{\circ} \mathrm{N}\right.$ minus $50-0^{\circ} \mathrm{W}, 40-60^{\circ} \mathrm{S}$ ), although the individual results will change slightly for the individual models.

There are several studies indicating a relationship between the large scale north-south density gradient and the overturning circulation, where a larger depth integrated density gradient is associated with a stronger overturning (Thorpe et al., 2001, and references therein). If more heat is transported into the sinking region (the region of highest density), a decreased density in this region will reduce the north-south density gradient and thus the inflow strength. The result will be gradually colder water and a reversed phase.

For the salt transport, the analogous mechanism with a freshwater anomaly in the sinking region will lead to a reduced north-south density gradient and reduce the strength of the overturning. This will increase the residence time of the water in sub-tropical Atlantic, give more net evaporation, and lead to a positive salinity anomaly being transported into the sinking region. This will in turn restore the north-south density gradient and speed up the overturning circulation. This mechanism is seen in a freshwater hosing experiment (Otterå et al., 2003). As the relative importance of the temperature and salinity anomalies in determining the density in the convective regions varies between the models, the mechanisms and thus the dominant time scales are expected to be highly model dependent (Delworth et al., 1993; Thorpe et al., 2001). Another reason for the differing time scales in the models, and probably also the relationship between AMO and AMOC, might be the location of the convective regions, which in many of the IPCC AR4 models is not simulated in the correct location.

If there is a direct link between the strength of the AMOC and the AMO, irrespective of which mechanisms are at play, the periodicities of the two time series should be expected to be similar. The models with the strongest overturning 
circulation would be expected to be the same as those having the shortest time scales if ocean advection is the dominant mechanism. For most models we find a clear link between the AMOC and AMO time scales, but no relation is found between the dominant time scales and the strength of the overturning. This clearly indicates that even if ocean advection (AMOC) plays an important role for the AMO variability, there are other factors such as non-predictable stochastic forcing from the atmosphere or externally forced variability that are masking the signal.

\section{Summary and concluding remarks}

Simulated variability in the North Atlantic has been investigated and compared with observations. Focus has been on the basin-scale averaged sea surface temperature variability known as the Atlantic Multidecadal Oscillation (AMO), and on the northward upper ocean transports associated with the Atlantic Meridional Overturning Circulation (AMOC). For the first time the full suit of IPCC AR4 atmosphereocean general circulation models have been used for this purpose. The models show most variability on multidecadal time scales in the North Atlantic sector both with respect to the AMO and AMOC indices, but with a large intermodel spread in both amplitudes and frequencies. The AMOC is found to lead the AMO in all models, and for 7 out of the 10 models showing most realistic AMOC strength, AMOC is close to being in phase with the rate-of-change of AMO suggesting that increased northward heat transport warms the surface ocean.

The spatial structures and amplitude of the simulated temperature anomalies are similar to the observed, but the models fail to capture the timing of the observed extremes, indicating that they are primarily due to internally generated variability and not externally forced.

Most models show a realistic structure of the overturning circulation. This includes both the upper North Atlantic (AMOC) cell and the lower Antarctic overturning cell, and 10 out of 18 models show values within the observationallybased estimate of the range of 13-24.3 Sv for the North Atlantic overturning.

Associated with a stronger AMOC the models shows a positive temperature anomaly and reduced sea ice extent in both the Nordic Seas and in the Labrador Sea compared to a weak AMOC.

Through advection of temperature/salinity anomalies there is a potential for decadal predictability of the SSTs if the AMOC state is known, through north-south density gradients. However, from the model results, it is not possible to identify a common mechanism responsible for the variability associated with the AMO, or evidence that observations of the surface properties of the ocean (e.g., AMO) automatically can be used as a proxy for the state of the overturning, as suggested by Collins et al. (2006), Smith et al. (2007) and
Keenlyside et al. (2008). Hence the road toward future operational decadal predictions of North Atlantic or global climate should involve a full 3-D assimilation of the state of the ocean, including both sea level height anomaly from satellites and hydrography, the latter being available through the Argo project (Roemmich and Owens, 2000; Gould, 2005). The study by Dunstone and Smith (2010) suggests that this might significantly improve the skills of the decadal predictions compared to only using the sea surface properties.

Acknowledgements. The project has been supported by the Research Council of Norway through the NorClim project, and is also contributing to the BIAC and DecCen projects. The authors would like to thank Asgeir Sorteberg for help throughout the work, and Nils Gunnar Kvamstø and David Stephenson for useful comments to an earlier draft. This is publication no. A338 from the Bjerknes Centre for Climate Research.

Edited by: M. Hecht

\section{References}

Baringer, M. O. and Molinari, R.: Atlantic Ocean baroclinic heat flux at 24 to $26^{\circ} \mathrm{N}$, Geophys. Res. Lett., 26, 353-356, 1999.

Bartlett, M. S.: An introduction to stochastic processes. Cambridge University Press, 1966.

Bentsen, M., Drange, H., Furevik, T., and Zhou, T.: Simulated variability of the Atlantic meridional overturning circulation, Clim. Dynam., 22, 701-720, doi:10.1007/s00382-004-0397-x, 2004.

Bjerknes, J.: Atlantic air-sea interaction, edited by: Landsberg, H. E. and Van Mieghem, J., Adv. Geophys., Academic press, 1-82, 1964.

Bryden, H. L., Longworth, H. R., and Cunningham, S. A.: Slowing of the Atlantic meridional overturning circulation at $25^{\circ} \mathrm{N}$, Nature, 438, 655-657, doi:10.1038/nature04385, 2005.

Collins, M., Botzet, M., Carril, A. F., Drange, H., Jouzeau, A., Latif, M., Masina, S., Otterå, O. H., Pohlmann, H., Sorteberg, A., Sutton, R., and Terray, L.: Interannual to decadal climate predictability in the North Atlantic: a multimodel-ensemble study, J. Climate, 19(7), 1195-1203, 2006.

Cunningham, S. A., Kanzow, T., Rayner, D., Baringer, M. O., Johns, W. E., Marotzke, J., Longworth, H. R., Grand, E. M., Hirschi, J. J. M., Beal, L. M., Meinen, C. S., and Bryden, H. L.: Temporal variability for the Atlantic Meridional Overturning Circulation at $26.5^{\circ} \mathrm{N}$, Science, 317, 935-937, doi:10.1126/science.1141304, 2007.

Delworth, T. L. and Knutson, T. R.: imulation of early 20th century global warming, Science, 287(5461), 2246-2250, 2000.

Delworth, T. L. and Mann, M. E.: Observed and simulated multidecadal variability in the Northern hemisphere, Clim. Dynam., 16, 661-676, 2000.

Delworth, T. L., Manabe, S., and Stouffer, R. J.: Interdecadal variation in the thermohaline circulation in a coupled oceanatmosphere model, J. Climate, 6, 1993-2011, 1993.

Delworth, T. L., Clark, P. U., Holland, M., Johns, W. E., Kuhlbrodt, T., Lynch-Stieglitz, J., Morrill, C., Seager, R., Weaver, A. J., and Zhang, R.: The potential for abrupt change in the Atlantic Meridional Overturning Circulation. Abrupt Climate Change, A report 
by the US, Climate Change Science Program and the Subcommittee on Global Change Research, US Geological Survey, Reston, VA, chap. 4, 117-162, 2008.

Deshayes, J. and Frankignoul, C.: Simulated variability of the circulation of the North Atlantic from 1953 to 2003, J. Climate, 21, 4919-4933, doi:11.1175/2008JCLI1882.1, 2008.

Dickson, R., Lazier, J., Meincke, J., Rhines, P., and Swift, J.: Longterm coordinated changes in the convective activity of the North Atlantic, Prog. Oceanogr., 38, 241-295, 1996.

Dunstone, N. J. and Smith, D. M.: Impact of atmosphere and subsurface ocean data on decadal climate prediction, Geophys. Res. Lett., 37, L02709, doi:10.1029/2009GL041609, 2010.

Eden, C. and Willebrand, J.: Mechanisms of interannual to decadal variability of the North Atlantic circulation, J. Climate, 14, 2266-2280, 2001.

Frankcombe, L. M., Dijkstra, H. A., and von der Heydt, A.: Noise-induced multidecadal variability in the North Atlantic: Excitation of normal modes, J. Phys. Oceanogr., 39, 220-233, doi:10.1175/2008JPO3951.1, 2009.

Frankignoul, C., Müller, P., and Zorita, E.: A simple model of the decadal response of the ocean to stochastic wind forcing, J. Phys. Oceanogr., 27, 1533-1546, 1997.

Fuglister, F. C.: Atlantic Ocean Atlas of temperature and salinity profiles and data from the international geophysical year of 1957-1958, Woods Hole Oceanogr Inst Atlas Series, Vol. 1, Woods Hole Oceanographic Institution, Woods Hole, Mass, 1960.

Furevik, T.: Annual and interannual variability of Atlantic Water temperatures in the Norwegian and Barents Seas: 1980-1996, Deep-Sea Res. Pt. I, 48(2), 383-404, 2001.

Furevik, T., Bentsen, M., Drange, H., Kindem, I. K. T., Kvamstø, N. G., and Sorteberg, A.: Description and evaluation of the Bergen climate model: ARPEGE coupled with MICOM, Clim. Dynam., 21, 27-51, doi:10.1007/s00383-003-0317-5, 2003.

Ganachaud, A.: Large-scale mass transports, water mass formation, and diffusivities estimated from World Ocean Circulation Experiment (WOCE) hydrographic data, J. Geophys. Res., 108(C7), 3213, doi:10.1029/2002JC001565, 2003.

Ganachaud, A. and Wunsch, C.: Improved estimates of global ocean circulation, heat transport and mixing from hydrographic data, Nature, 408, 453-457, 2000.

Gijbels, I., Pope, A., and Wand, M. P.: Understanding exponential smoothing via kernel regression, J. R. Stat. Soc. B, 61(1), 39-50, 1999.

Gould, J.: From shallow floats to Argo - The development of neutrally buoyant floats, Deep-Sea Res. Pt. II, 52, 529-543, 2005.

Hansen, J., Nazarenko, L., Ruedy, R., Sato, M., Willis, J., Del Genio, A., Koch, D., Lacis, A., Lo, K., Menon, S., Navakov, T., Perlwiz, J., Russel, G., Schmidt, G. A., and Tausenev, N.: Earth's energy imbalance: confirmation and implications, Science, 308, 1431, doi:10.1126/science.1110252, 2005.

Hasselmann, K.: Stochastic climate models Part I. Theory, Tellus, 28, 473-483, 1976.

Hawkins, E. and Sutton, R.: Variability of the Atlantic thermohaline circulation described by three-dimensional empirical orthogonal functions, Clim. Dynam., 29, 745-762, doi:10.1007/s00382007-0263-8, 2007.

Häkkinen, S.: Variability of the simulated meridional heat transport in the North Atlantic for the period 1951-1993, J. Geophys. Res.,
104(C5), 10991-11007, 1999.

Hurrell, J. W., Kushnir, Y., Ottersen, G., and Visbeck, M.: An overview of the North Atlantic Oscillation, The North Atlantic Oscillation: Climatic significance and environmental impact, edited by: Hurrell, J. W., Kushnir, Y., Ottersen, G., and Visbeck, M., American Geophysical Union, Geoph. Monog. Series, 134, 1-35, 2003.

IPCC, 2007: Climate Change 2007: The physical science basis. Contribution of Working Group I to the Fourth Assessment Report of the Intergovernmental Panel on Climate Change, Cambridge University Press, Cambridge, United Kingdom and New York, NY, USA.

Johnson, G. C.: Quantifying Antarctic Bottom Water and North Atlantic Deep Water volumes, J. Geophys. Res., 113, C05027, doi:10.1029/2007JC004477, 2008.

Jungclaus, J. H., Haak, H., Latif, M., and Mikolajewicz, U.: ArcticNorth Atlantic interactions and multidecadal variability of the meridional overturning circulation, J. Climate, 18(19), 40134031, 2005.

Kaplan, A., Cane, M., Kushnir, Y., Clement, A., Blumenthal, M., and Rajagopalan, B.: Analyses of global sea surface temperature 1856-1991, J. Geophys. Res., 103, 18567-18589, 1998.

Keenlyside, N. S., Latif, M., Jungclaus, J., Kornblueh, L., and Roeckner, E.: Advancing decadal-scale climate prediction in the North Atlantic sector, Nature, 453, 84-88, doi:10.1038/nature06921, 2008.

Knight, J. R.: The Atlantic Multidecadal Oscillation inferred from the forced climate response in coupled general circulation models, J. Climate, 22, 1610-1625, doi:10.1175/2008JCLI2628.1, 2009.

Knight, J. R., Allan, R. J., Folland, C. K., Vellinga, M., and Mann, M. E.: A signature of persistent natural thermohaline circulation cycles in observed climate, Geophys. Res. Lett., 32, L20708, doi:10.1029/2006GL026242, 2005.

Kravtsov, S. and Spannagle, C.: Multidecadal climate variability in observed and modeled surface temperatures, J. Climate, 21, 1104-1121, doi:10.1175/2007JCLI1874.1, 2008.

Kushnir, Y.: Interdecadal variations in North Atlantic sea surface temperature and associated atmospheric conditions, J. Climate, 7(1), 141-157, 1994.

Latif, M., Roeckner, E., Botzet, M., Esch, M., Haak, H., Hagemann, S., Jungclaus, J. H., Legutke, S., Marsland, S., and Mickolajevicz, U.: Reconstructing, monitoring, and predicting multidecadal-scale changes in the North Atlantic thermohaline circulation with sea surface temperature, J. Climate, 17, 16051613, 2004.

Lumpkin, R. and Speer, K.: Large-scale vertical and horizontal circulation in the North Atlantic Ocean, J. Phys. Oceanogr., 33, 1902-1920, 2003.

Marshall, J., Kushnir, Y., Battisti, D., Chang, P., Czaja, A., Dickson, R., Hurrell, J., McCartney, M., Saravanan, R., and Visbeck, M.: North Atlantic climate variability: Phenomena, impacts and mechanisms, Int. J. Climatol., 21, 1863-1898, 2001.

Medhaug, I., Langehaug, H. R., Eldevik, T., Furevik, T., and Bentsen, M.: Mechanisms for decadal scale variability in a simulated Atlantic Meridional Overturning Circulation, Clim. Dynam., in revision, 2011.

Msadek, R. and Frankignoul, C.: Atlantic multidecadal oceanic variability and its influence on the atmosphere in a climate 
model, Clim. Dynam., 33, 45-62, doi:10.1007/s00382-0080452-0, 2009.

Otterå, O. H., Drange,H., Bentsen, M., Kvamstø, N. G., and Jiang, D.: The sensitivity of the present-day Atlantic meridional overturning circulation to freshwater forcing, Geophys. Res. Lett., 30(17), 1898, doi:10.1029/2003GL017578, 2003.

Otterå, O. H., Bentsen, M., Drange, H., and Suo, L.: External forcing as a metronome for Atlantic multidecadal variability, Nat. Geosci., 3, 688-694, doi:10.1038/ngeo955, 2010.

Parrilla, G., Lavn, A., Bryden, H., and Millard, R.: Rising temperatures in the subtropical North Atlantic Ocean over the past 35 years, Nature, 369, 48-51, 1994.

Pohlmann, H., Jungclaus, J., Köhl, A., Stammer, D., and Marotzke, J.: Initializing decadal climate prediction with the GECCO oceanic synthesis: Effects on the North Atlantic, J. Climate, 22, 3926-3938, 2009.

Polyakov, I. V. and Johnson, M. A.: Arctic decadal and interdecadal variability, Geophys. Res. Lett., 27(24), 4097-4100, 2000.

Polyakov, I. V., Alekseev, G. V., Timikhov, L. A., Bhatt, U. S., Colony, R. L., Simmons, H. L., Walsh, D., Walsh, J. E., and Zakharov, V. F.: Variability of the Intermediate Atlantic Water of the Arctic Ocean over the last 100 years, J. Climate, 17(23), 4485-4497, 2004.

Quenouille, M. H.: Associated Measurements, Butterworths, London, 241 pp., 1952.

Roemmich, D. and Owens, W. B.: The Argo project: Global ocean observations for understanding and prediction of climate variability, Oceanogr., 13, 45-50, 2000.

Roemmich, D. and Wunsch, C.: Two transatlantic sections: meridional circulation and heat flux in the subtropical North Atlantic Ocean, Deep-Sea Res., 32, 619-664, 1985.

Schlesinger, M. E. and Ramankutty, N.: An oscillation in the global climate system of period 65-70 years, Nature, 367, 723-726, 1994.

Schott, F. A., McCreary Jr, J. P., and Johnson, G. C.: Shallow overturning circulation of the tropical-subtropical oceans, Earth Climate: The Ocean-Atmosphere Interaction, edited by: Wang, C., Xie, S., and Carton, J. A., American Geophysical Union, Geoph. Monog. Series, 147, 261-304, 2004.

Smethie, W. M. and Fine, R. A.: Rates of North Atlantic deep water formation calculated from chlorofluorocarbon inventories, DeepSea Res. Pt. I, 48, 189-215, 2001.

Smith, D. M., Cusack, S., Colman, A. W., Folland, C. K., Harris, G. R., and Murphy, J. M.: Improved surface temperature prediction for the coming decade from a global climate model, Science, 317, 796-799, doi:10.1126/science.1139540, 2007.
Sutton, R. T. and Hodson, D. L. R.:Atlantic Ocean forcing of North American and European summer climate, Science, 309(5731), 115-118, doi:10.1126/science.110949, 2005.

Talley, L. D., Reid, J. L., and Robbins, P. E.: Data-based meridional overturning streamfunctions for the global ocean, J. Climate, 16, 3213-3226, 2003.

Thompson, D. J.: Spectrum estimation and harmonic analysis, $\mathrm{P}$ IEEE, 70(9), 1055-1096, 1982.

Thompson, D. W. J., Kennedy, J. J., Wallace, J. M., and Jones, P. D.: A large discontinuity in the mid-twentieth century in observed global-mean surface temperature, Nature, 453, 646-649, doi:10.1038/nature06982, 2008.

Thorpe, R. B., Gregory, J. M., Johns, T. C., Wood, R. A., and Mitchell, J. F. B.: Mechanisms determining the Atlantic thermohaline circulation response to greenhouse gas forcing in a nonflux-adjusted coupled climate model, J. Climate, 14, 3102-3116, 2001.

Ting, M., Kushnir, Y., Seager, R., and Li, C.: Forced and internal twentieth-century SST trends in the North Atlantic, J. Climate, 22, 1469-1481, doi:10.1175/2008JCLI2561.1, 2009.

Trenberth, K. E. and Caron, J. M.: Estimates of meridional atmosphere and ocean heat transports, J. Climate, 14, 3433-3443, 2001.

Vellinga, M. and Wu, P.: Low-latitude freshwater influence on centennial variability of the Atlantic thermohaline circulation, J. Climate, 17, 4498-4511, doi:10.1175/3219.1, 2004.

Woodgate, R. A., Aagaard, K., and Weingartner, T. J.: Monthly temperature, salinity, and transport variability of the Bering Strait through flow, Geophys. Res. Lett., 32, L04601, doi:10.1029/2004GL021880, 2005.

Wunsch, C.: What is the thermohaline circulation?, Science, 298, 1180-1181, 2002.

Zhang, R.: Anticorrelated multidecadal variations between surface and subsurface tropical North Atlantic, Geophys. Res. Lett., 34, L12713, doi:10.1029/2007GL030225, 2007.

Zhang, R.: Coherent surface-subsurface fingerprint of the Atlantic meridional overturning circulation, Geophys. Res. Lett., 35, L20705, doi:10.1029/2008GL035463, 2008.

Zhang, R., Delworth, T. L., and Held, I. M.: Can the Atlantic Ocean drive the observed multidecadal variability in Northern Hemisphere mean temperature?, Geophys. Res. Lett., 34, L02709, doi:10.1029/2006GL028683, 2007. 